\title{
Review: Nutrient, Fiber, and Bioactive Content of Fruit Pomace, Major By-product of Juice Industry
}

\author{
Florence Ignatia $^{1}$, Kezia Meivira ${ }^{1}$, Irvan Setiadi Kartawiria ${ }^{1}$, Maria D.P.T. \\ Gunawan-Puteri ${ }^{1, *}$ \\ ${ }^{1}$ Faculty of Life Sciences and Technology, Swiss German University, Tangerang, 15143, Indonesia \\ *Corresponding author.Email: maria.gunawanputeri@sgu.ac.id
}

\begin{abstract}
The market of the juice industry is increasing globally including in Indonesia and one of the factors that support the developing market of juice is the sufficient supply of raw material. Consequently, the increasing production of juice has resulted in a high amount of solid waste such as under-ripe fruits, rotten organic matter, peels, seeds, and majorly in the form of pomace. Pomace is usually discarded or slightly used as animal feed and becomes a serious environmental problem, and also an economic burden for the company. However, pomace can be utilized as functional and healthy ingredients in food product development due to its beneficial components namely dietary fiber and antioxidants. This review will emphasize on the nutrient, fiber and bioactive content of fruit pomace.
\end{abstract}

Keywords: Fruit Juice, Food Waste, Pomace, Antioxidants, Dietary Fiber

\section{INTRODUCTION}

The increasing world population and the changing of dietary habits has increased the demand for the production of fruits [1] The production of fresh fruits globally reached 883.42 million metric tons in 2019, which was an increase of $53.20 \%$ from 2000 [2]. Fruits can be consumed directly or processed by the beverage industry. One of the beverage industry segments is the juice industry. In general, fruit juice means an extract of a watery part in cells or tissues of fruits by mechanically squeezing or pressing out without using any solvent or heat. Due to the awareness of health, juice is chosen by consumers as it is a natural and healthy product and provides nutritional benefits to the human body which boosts [3].

The juice market is increasing globally and one of the most promising segments in the beverage industry. The market of juice is dependent on the availability of the raw material, geographical distribution and the health awareness of consumers themselves [4]. Based on the compound annual growth rate (CAGR) calculation for 2021-2025, the market of juice is predicted to grow annually by $5.60 \%$ worldwide [5] and in Indonesia itself, the market of juices is predicted to grow annually by $7.39 \%$ [6]. The leading juice company in Indonesia is Coca Cola Indonesia through its Minute Maid brand and first marketed as Minute Maid Pulpy Orange. Another leading juice company is Buavita from PT. Unilever Indonesia with variant fruits such as orange, apple, mango, guava and lychee [7]. Another juice company in Indonesia that is popular for its cold-pressed juice is Rejuve from PT. Sewu Central Primatama and the most used fruit for juice is pineapple [8].

Processing of fruits by the juice industry results in huge amounts of waste every year that is a worldwide problem for both environmental and economic aspects [9]. The waste consists of over or under-ripe fruits, rotten organic matter, pomace, seeds, and peels [10]. Pomace is the largest proportion of solid waste (by-product) left in the fruit processing. About $25 \%-35 \%$ of pomace comes from the mass of raw material [11] and about over 400,000 tons of pomace are produced every year [12]. It is usually disposed of in landfills and only a part of it is reused for animal feeding and land fertilizer. Disposal of fruit pomace is considered environmental pollution as it has high organic matter content [9]. Pomace also has high water content which makes it hard to be composted well and develop a high risk of undesired microbes' growth [12]. A high amount of pomace not only impacts the environment but is an economic burden for the company regarding their management as waste always costs money [13]. On the other hand, there is a tendency to look for new and more natural sources of general and functional 
food ingredients from fruit by-products [14]. Due to the presence of valuable nutrients and dietary fiber [15], pomace may fulfil this demand as it is also natural and relatively low-cost material [16]. For instance, Tropicana has utilized the orange pomace from its orange juice and has added $25 \%$ of orange pomace in its orange juice to increase the dietary fiber content and provided $39 \%$ recommended daily intake of vitamin C [17]. Moreover, the reduction of renewable resources and land for cultivation, continuous growth of the world population and the mismanagement of waste are the factors to utilize the by-product in the food sector [15]. However, the scientific studies regarding fruit pomace from the juice industry in Indonesia are still limited. This review will emphasize on the nutrient, fiber and bioactive content of fruit pomace.

\section{REVIEW}

\subsection{Nutrient and Bioactive Content of Fruit Pomace from Juice Industry}

Fruit pomace contains significant amounts of phytochemicals [18], vitamin, minerals [11] and/or polymeric materials such as pectin and lignocellulose compounds [19]. Phytochemicals are antioxidant compounds such as phenolics and carotenoids that can prevent oxidative stress caused by oxidation and reduce the risk of major chronic disease [20]. Antioxidant compounds can increase the stability of food products as they prevent lipid peroxidation [14].

Both macro- and micro- nutrients are required for our body to process correctly [43]. Table 1 shows that fruit pomaces vary in both macronutrients and minerals content. A study interestingly stated that apples contain majorly higher macro- and micro-nutrients in the form of pomace than whole [22]. Apple and orange pomace have the highest amount of carbohydrates and ashes. However, Hussein et al. (2007) found that apple pomace has a total sugar level $(4.43 \%)$ which is considered as low compared to pineapple (9.75\%) and mango (40\%) pomaces [23].

Iron content in 100 gr pomaces from apples (37.34 $\mathrm{mg}$ ) and guavas $(13.8 \mathrm{mg})$ meet the adult recommended daily intake which is $8-18 \mathrm{mg}$ per day [43]. Additionally, apple and orange pomace comprise 250 and $160 \mathrm{mg}$ phosphorus per $100 \mathrm{gr}$, respectively. These values are considered high compared to pineapple (4 mg/100g). Protein content in major fruit pomaces is below $10 \%$. Orange pomace has the highest protein (6.00-7.90\%) and pomace made out of albedo and oleiferous sacs contain the highest amount of fat $(6.57 \%)$ [26]. Furthermore, 100 gr of orange pomace contains $770 \mathrm{mg}$ of calcium, approximately $70 \%$ of calcium recommended daily intake (1000-1200 mg) [43].
Fruit pomaces do not only carry beneficial macroand micro-nutrients, but they also contain bioactive components as shown in Table 2. Apple pomace shows a good source of polyphenols [44][45]. It is shown by its flavonoid content of 91-200 mg Quercetin Equivalent in $100 \mathrm{~g}$ pomace. Đilas et al. (2009) reviewed that the major identified polyphenols compounds in apple pomace are catechins, phloretin glycosides, quercetin glycosides, hydroxycinnamates, and procyanidins [45].

The total phenolic content in both air dried and sun dried orange pomace is considered as moderate at 43.5$48.89 \mathrm{mg}$ Gallic Acid Equivalent/100g pomace [46]. Sun et al. (2012) found that several cinnamics (caffeic, pcoumaric, and ferulic) and benzoics (protocatechuic, phydroxybenzoic, and vanillic) were detected [37]. Compounds such as lutein and carotene were also found [38].

Denny et al. (2013) shows that total phenolic content in guava pomace is $3.4 \mathrm{mg} \mathrm{GAE} / \mathrm{g}$ which is considered as low [46] and the identified compounds are quercetin, epicatechin, myricetin, gallic acids and isovanillic which have anti-inflammatory and antinociceptive effects [41]. However, guava have the highest ascorbic acid compared to pomace of other fruits, and carotene which can be converted into vitamin A [43].

The highest carotene content $(2140-2330 \mu \mathrm{g} / \mathrm{g})$ was obtained from fresh mango pomace. Pomaces from mango also contain lutein. The ash, protein, insoluble and soluble dietary fiber and -carotene of dried mango pomace are higher while the other contents are lower than the non-dried mango pomace. The total phenolic content of mango pomace is also considered as low [46].

\subsection{Dietary Fiber in Fruit Pomace from Juice Industry}

Dietary fiber represents plant substances that are hard to be digested by digestive enzymes in the human body and contain polysaccharides within the cell. In chemical terms, dietary fiber is defined as non-starch polysaccharides and lignin, non structural components (gums) and additives (commercial gums, modified cellulose and pectin) [47]. Fruit pomace that is left after juice processing is a good source of dietary fiber due to high dietary fiber content [48], has beneficial physiological effects that may exert on human health and has good functional properties [49].

Dietary fiber can be classified into soluble (pectin and gums) and insoluble (cellulose, lignin and hemicellulose) dietary fiber. Soluble dietary fiber forms viscous gel when dissolved in water, while insoluble dietary fiber does not form gels due to its insolubility [50]. Their ratio is important for dietary and functional properties. The ratio for soluble and insoluble dietary fiber to be used as food ingredients should be close to $1: 2$ [47]; [51]). Functional properties of dietary fiber that can be used in 
Table 1. Nutritive values of several fruit pomaces

\begin{tabular}{|c|c|c|c|c|c|c|c|c|c|}
\hline \multirow{2}{*}{$\begin{array}{l}\text { Pomace } \\
\text { Source }\end{array}$} & \multirow{2}{*}{ Treatment } & \multicolumn{2}{|c|}{ Carbohydrate } & \multirow{2}{*}{ Protein } & \multirow{2}{*}{ Fat } & \multicolumn{3}{|c|}{ Ash } & \multirow{2}{*}{ References } \\
\hline & & $\begin{array}{c}\text { Total } \\
\text { Sugar }\end{array}$ & $\begin{array}{c}\text { Reducing } \\
\text { Sugar }\end{array}$ & & & $\mathrm{Fe}$ & $\mathbf{C a}$ & $\mathbf{P}$ & \\
\hline Apple & Freeze Dried & \multicolumn{2}{|c|}{$84.76 \%$} & $2.65 \%$ & $2.53 \%$ & \multicolumn{3}{|c|}{$1.79 \%$} & {$[21]$} \\
\hline Apple & n.s. & \multicolumn{2}{|c|}{$44.5-57.4 \%$} & $2.7-5.3 \%$ & $1.1-3.6 \%$ & \multicolumn{3}{|c|}{$0.50-6.10 \%$} & {$[22]$} \\
\hline Apple & Fresh & $4.43 \%$ & $3.22 \%$ & $3.68 \%$ & $3.16 \%$ & $\begin{array}{c}37.34 \mathrm{mg} / \\
100 \mathrm{~g}\end{array}$ & $\begin{array}{c}8.25 \mathrm{mg} / \\
100 \mathrm{~g}\end{array}$ & $\begin{array}{c}250 \mathrm{mg} / \\
100 \mathrm{~g}\end{array}$ & {$[23]$} \\
\hline Orange & Freeze Dried & \multicolumn{2}{|c|}{$77.78 \%$} & $6.81 \%$ & $2.14 \%$ & \multicolumn{3}{|c|}{$4.18 \%$} & [21] \\
\hline Orange & $\begin{array}{l}\text { Washed, Air } \\
\text { Dried }\end{array}$ & \multicolumn{2}{|c|}{$17.90 \%$} & $6.70 \%$ & $0.89 \%$ & \multicolumn{3}{|c|}{$2.71 \%$} & {$[24]$} \\
\hline Orange & $\begin{array}{c}\text { Washed, Air } \\
\text { Dried }\end{array}$ & \multicolumn{2}{|c|}{$88.00 \%$} & $7.90 \%$ & $0.50 \%$ & \multicolumn{3}{|c|}{$2.90 \%$} & [25] \\
\hline Orange & Air Dried & \multicolumn{2}{|c|}{ n.s. } & $0.43 \%$ & $6.57 \%$ & \multicolumn{3}{|c|}{$3.43 \%$} & [26] \\
\hline Orange & n.s. & \multicolumn{2}{|c|}{ n.s. } & $6.00 \%$ & n.s. & n.s. & $\begin{array}{c}770 \\
\mathrm{mg} / 100 \mathrm{~g}\end{array}$ & $\begin{array}{c}160 \mathrm{mg} / \\
100 \mathrm{~g}\end{array}$ & {$[27]$} \\
\hline Orange & n.s. & \multicolumn{2}{|c|}{$9-14 \%$} & $1-2 \%$ & $<0.5 \%$ & \multicolumn{3}{|c|}{ n.s. } & {$[28]$} \\
\hline Guava & n.s. & \multicolumn{2}{|c|}{$11.84-12.19 \%$} & $\begin{array}{l}1.01- \\
1.78 \%\end{array}$ & $\begin{array}{l}0.07- \\
1.2 \%\end{array}$ & $\begin{array}{c}13.8 \mathrm{mg} / \\
100 \mathrm{~g}\end{array}$ & n.s. & n.s. & [29]; [27] \\
\hline Pineapple & Sun Dried & \multicolumn{2}{|c|}{$43.46 \%$} & $4.71 \%$ & $0.61 \%$ & $5 \mathrm{mg} / 100 \mathrm{~g}$ & $\begin{array}{c}10 \mathrm{mg} / \\
100 \mathrm{~g}\end{array}$ & $\begin{array}{c}4 \mathrm{mg} / \\
100 \mathrm{~g}\end{array}$ & {$[30]$} \\
\hline Pineapple & Freeze Dried & \multicolumn{2}{|c|}{$42.85 \%$} & $4.65 \%$ & $0.62 \%$ & \multicolumn{3}{|c|}{$2.21 \%$} & [31] \\
\hline Pineapple & Freeze Dried & \multicolumn{2}{|c|}{$43.46 \%$} & $4.71 \%$ & $0.61 \%$ & \multicolumn{3}{|c|}{$2.24 \%$} & {$[32]$} \\
\hline Pineapple & Air Dried & $9.75 \%$ & $8.20 \%$ & $0.01 \%$ & n.s. & \multicolumn{3}{|c|}{$0.04 \%$} & {$[33]$} \\
\hline Mango & Fresh & n.s. & $10-12 \%$ & n.s. & n.s. & \multicolumn{3}{|c|}{ n.s. } & {$[34]$} \\
\hline Mango & Washed & $40 \%$ & $34.67 \%$ & $3.54 \%$ & n.s. & \multicolumn{3}{|c|}{$0.86 \%$} & [35] \\
\hline Mango & $\begin{array}{l}\text { Washed, Air } \\
\text { Dried }\end{array}$ & $18.76 \%$ & $14.3 \%$ & $4.30 \%$ & n.s. & \multicolumn{3}{|c|}{$0.01 \%$} & {$[35]$} \\
\hline
\end{tabular}

Table 2. Bioactive components of several fruit pomace

\begin{tabular}{|c|c|c|c|c|c|c|c|c|}
\hline $\begin{array}{l}\text { Pomace } \\
\text { Source }\end{array}$ & $\begin{array}{c}\text { Treatme } \\
\text { nt }\end{array}$ & $\begin{array}{c}\text { Total } \\
\text { Phenolics }\end{array}$ & $\begin{array}{c}\text { Total } \\
\text { Flavonoids }\end{array}$ & Tannin & Lutein & Carotene & $\begin{array}{c}\text { Ascorbic } \\
\text { Acid }\end{array}$ & References \\
\hline Apple & $\begin{array}{c}\text { Oven } \\
\text { dried, } \\
\text { Freeze } \\
\text { Dried, } \\
\text { Sun Dried }\end{array}$ & $\begin{array}{l}3.98-5.78 \\
\mathrm{mg} \text { GAE/g }\end{array}$ & $\begin{array}{c}91-200 \mathrm{mg} \mathrm{QE} / \\
100 \mathrm{~g}\end{array}$ & n.s. & n.s. & n.s. & n.s. & [36] \\
\hline Apple & $\begin{array}{l}\text { Fresh (a), } \\
\text { Jammed } \\
\text { (b) }\end{array}$ & $\begin{array}{c}0.83 \mathrm{mg} \\
\mathrm{GAE} / \mathrm{g}(\mathrm{b})\end{array}$ & $\begin{array}{c}30.10 \mathrm{mg} \mathrm{CAT} / \\
100 \mathrm{~g}(\mathrm{~b})\end{array}$ & n.s. & n.s. & n.s. & $\begin{array}{c}13.3 \\
\mathrm{mg} / 100 \mathrm{~g}(\mathrm{a})\end{array}$ & [23] \\
\hline Orange & Sun Dried & $\begin{array}{c}43.50 \mathrm{mg} \\
\mathrm{GAE} / \mathrm{g}\end{array}$ & n.s. & n.s. & n.s. & n.s. & n.s. & [37] \\
\hline Orange & Air Dried & $\begin{array}{c}48.89 \mathrm{mg} \\
\mathrm{GAE} / \mathrm{g}\end{array}$ & n.s. & n.s. & n.s. & n.s. & n.s. & [26] \\
\hline Orange & Fresh & n.s. & n.s. & n.s. & $7.89 \mu \mathrm{g} / \mathrm{g}$ & $43.4 \mu \mathrm{g} / \mathrm{g}$ & n.s. & {$[38]$} \\
\hline Orange & n.s. & n.s. & n.s. & n.s. & n.s. & n.s. & $\begin{array}{c}20-50 \mathrm{mg} / \\
100 \mathrm{~g}\end{array}$ & {$[28]$} \\
\hline Guava & n.s. & n.s. & n.s. & n.s. & n.s. & $1250 \mu \mathrm{g} / \mathrm{g}$ & $\begin{array}{c}87.44 \\
\mathrm{mg} / 100 \mathrm{~g}\end{array}$ & [27] \\
\hline Guava & $\begin{array}{l}\text { Frozen, } \\
\text { Thawed }\end{array}$ & $\begin{array}{c}0.09 \mathrm{mg} \\
\mathrm{GAE} / \mathrm{g}\end{array}$ & $\begin{array}{c}0.40 \mathrm{mg} \mathrm{QE} / \\
100 \mathrm{~g} \\
\end{array}$ & $\begin{array}{c}62.6 \mathrm{mg} \\
/ 100 \mathrm{~g}\end{array}$ & n.s. & n.s. & $\begin{array}{c}40-440 \\
\mathrm{mg} / 100 \mathrm{~g}\end{array}$ & [39]; [40] \\
\hline Guava & Air Dried & $\begin{array}{l}3.40 \mathrm{mg} \\
\mathrm{GAE} / \mathrm{g}\end{array}$ & n.s. & n.s. & n.s. & n.s. & n.s. & [41] \\
\hline Pineapple & Air Dried & $\begin{array}{c}0.14 \mathrm{mg} \\
\mathrm{GAE} / \mathrm{g}\end{array}$ & $\begin{array}{l}0.5807 \mathrm{mg} \\
\text { Rutin/100g } \\
\end{array}$ & n.s. & n.s. & n.s. & $\begin{array}{c}26.5 \mathrm{mg} / \\
100 \mathrm{~g}\end{array}$ & {$[33] ;[42]$} \\
\hline Mango & Fresh & n.s. & n.s. & n.s. & n.s. & $2140-2330 \mu \mathrm{g} / \mathrm{g}$ & n.s. & {$[34]$} \\
\hline Mango & Washed & $1.05 \mathrm{mg} / \mathrm{g}$ & $42 \mathrm{mg} / 100 \mathrm{~g}$ & n.s. & $8.3 \mu \mathrm{g} / \mathrm{g}$ & $8.9 \mu \mathrm{g} / \mathrm{g}$ & n.s. & {$[35]$} \\
\hline Mango & $\begin{array}{c}\text { Washed, } \\
\text { Air Dried } \\
\end{array}$ & $1.00 \mathrm{mg} / \mathrm{g}$ & $28 \mathrm{mg} / 100 \mathrm{~g}$ & n.s. & $5.1 \mu \mathrm{g} / \mathrm{g}$ & $30.5 \mu \mathrm{g} / \mathrm{g}$ & n.s. & [35] \\
\hline
\end{tabular}


formulation of food products are water holding capacity, oil holding capacity, gel formation, swelling capacity [48].

In the organism, dietary fiber has the ability to absorb many harmful components by reducing cholesterol, and binding mineral compounds and heavy metal. Hemicellulose and pectin show remarkable ability to bind heavy metal. It is also proven to be cellulose and lignin, to a smaller extent than hemicellulose and pectin. The sorbing capacity of dietary fiber is determined by its origin, condition (temperature and $\mathrm{pH}$ ) and the type of metal. With this epidemiological data, the correlation of civilization-induced diseases and low dietary fiber in the diet is revealed. The diseases are obesity, atherosclerosis, diabetes, tooth decay, and chronic constipation [47]; [52]. With the consumption of high intake fiber will lower the risk of coronary heart diseases, stroke, hypertension, diabetes, obesity. It will also lower blood pressure and cholesterol level [53]. Based on Minister of Health Regulation No. 28 Yr 2019 about the recommended nutritional adequacy rate for Indonesian people, using the energy guideline of $2200 \mathrm{kcal} / \mathrm{day}$ for women (19-49 y.o.) and $2600 \mathrm{kcal} / \mathrm{day}$ for men (19-49 y.o.), the recommended daily dietary fiber intake is $31 \mathrm{~g} /$ day for adult women and $36 \mathrm{~g} /$ day for adult men [54].

Commercialized dietary fiber powder has several main characteristics which are total dietary fiber content above $50 \%$, moisture lower than $9 \%$, low content of lipids, a low caloric value and neutral flavor and taste, also perform in a satisfying manner as food ingredients. It not only affects the physiological properties, but also the sensorial properties of the food product. Food products have been mainly using cereal as the source of dietary fiber. However, dietary fiber from fruit pomace has more advantages than cereal such as high quality of total and soluble dietary fiber content, good functional properties (water holding capacity, oil absorption capacity, and gel formation), low caloric value, good colonic fermentability and lower amounts of antinutritional contents ([51]; [48]. Moreover, cereals contain more insoluble dietary fiber, which is mainly related to intestinal regulation, while dietary fiber from fruits contain more soluble dietary fiber which can help lower blood cholesterol and glucose intestinal absorption [55]. Pomace from fruit juices has been studied for their total, soluble, and insoluble fiber content (Table 3).

Kodagoda and Marapana (2017) reviewed the dietary fiber content in apple pomace consisting of 35-60\% of total dietary fiber with $14.6 \%$ soluble and $36.5 \%$ insoluble dietary fiber [14]. Younis and Ahmad (2015) analyzed the dietary fiber content in apple pomace and resulted in a higher amount of total and insoluble dietary fiber with $62.3 \%$ and $54.12 \%$ respectively, but a lower amount of soluble dietary fiber with $8.55 \%$ [56]. Kolodziejczyk et al. (2007) also analyzed the dietary fiber content in apple pomace [57] and the results were similar with Younis and Ahmad (2015) with 60.9\% total dietary fiber and $7.7 \%$ of soluble dietary fiber [56]. Apple pomace consists of $10-15 \%$ pectin. Pectin from apple pomace has more superior gelling properties than citrus pectin but it presents a brown hue that may limit its uses for light-colour foods [10]. Apple pomace also contains high amounts of lignin [48]. Struck and Rohm (2019) reviewed the content in apple pomace which consist of $4.26 \%-24.40 \%$ of hemicellulose, $7.2 \%-43.6 \%$ of cellulose, $15.3 \%-23.5 \%$ of lignin, $3.5 \%-14.32 \%$ of pectin and $4.7 \%-51.1 \%$ of fiber [18].

Kumar et al. (2018) and Selani et al. (2014) observed the dietary fiber content in pineapple pomace and resulted in a similar amount of dietary fiber [31],[32]. Kumar et al. (2018) got $44.38 \%$ of total dietary fiber with $0.62 \%$ of soluble and $43.46 \%$ of insoluble dietary fiber [31], while Selani et al. (2014) got $45.22 \%$ of total dietary fiber with $0.78 \%$ of soluble and $44.44 \%$ of insoluble dietary fiber in pineapple pomace [32]. Ocen and $\mathrm{Xu}$ (2013) analyzed the dietary fiber content in orange pomace and resulted in $71 \%$ of total dietary fiber, $17.97 \%$ soluble dietary fiber and $53.07 \%$ of insoluble dietary fiber [26]. Romero-Lopez et al. (2011) also analyzed the dietary fiber content in orange pomace [58] and got lower results than Ocen and $\mathrm{Xu}$ (2013) with $41.5 \%$ of total dietary fiber, $18.6 \%$ soluble dietary fiber and $22.9 \%$ of insoluble dietary fiber [26]. However, Ramadan (2012) got higher dietary fiber content in orange pomace than Romero-Lopez et al. (2011) with $54.21 \%$ of total dietary fiber, $24.71 \%$ of soluble dietary fiber and $29.47 \%$ of soluble dietary fiber and $29.47 \%$ of insoluble dietary fiber [59], [58].

Table 3. List of total (TDF), soluble (SDF) and insoluble (IDF) dietary fiber content in the fruit pomace for juice

\begin{tabular}{|c|c|c|c|c|}
\hline \multirow{2}{*}{ Product } & $\begin{array}{c}\text { TDF } \\
(\boldsymbol{\%})\end{array}$ & $\begin{array}{c}\text { SDF } \\
(\boldsymbol{\%})\end{array}$ & $\begin{array}{c}\text { IDF } \\
(\boldsymbol{\%})\end{array}$ & References \\
\hline \multirow{3}{*}{ Apple } & $35-60$ & 14.6 & 36.5 & {$[14]$} \\
\cline { 2 - 5 } & 60.9 & 7.7 & - & {$[57]$} \\
\cline { 2 - 5 } & 62.67 & 8.55 & 54.12 & {$[56]$} \\
\hline \multirow{2}{*}{ Pineapple } & 44.38 & 0.62 & 43.46 & {$[31]$} \\
\cline { 2 - 5 } & 45.22 & 0.78 & 44.44 & {$[32]$} \\
\hline \multirow{3}{*}{ Orange } & 71.04 & 17.97 & 53.07 & {$[26]$} \\
\cline { 2 - 5 } & 41.5 & 18.6 & 22.9 & {$[58]$} \\
\cline { 2 - 5 } & 54.21 & 24.71 & 29.47 & {$[59]$} \\
\hline \multirow{3}{*}{ Mango } & 88 & 9 & 79 & {$[60]$} \\
\cline { 2 - 5 } & - & $19.2-$ & $38.9-$ & {$[35]$} \\
\hline Guava & 63.9 & - & 63.55 & {$[27]$} \\
\hline
\end{tabular}


Guava pomace contained $63.9 \%$ of total dietary fiber and $63.55 \%$ of insoluble dietary fiber [27]. Mango pomace contained $88 \%$ of total dietary fiber, $9 \%$ of soluble dietary fiber and $79 \%$ of insoluble dietary fiber [60]. (Sudha et al., 2015) analyzed the dietary fiber content of both fresh and dried mango pomace and found a higher percentage of dietary fiber in the dried than fresh mango pomace. Dried mango pomace contained $43.1 \%$ insoluble and $20.9 \%$ soluble dietary fiber, while fresh mango pomace contained $38.9 \%$ insoluble and $19.2 \%$ soluble dietary fiber [35]. Mango pomace contains $0.03 \%$ of both cellulose and lignin [34].

\section{CONCLUSION}

Huge amounts of pomace resulted from the fruit juice industry becoming a serious problem worldwide including Indonesia that should be utilized. The utilization of fruit pomace may be toward the food sector as fruit pomace has valuable compounds such as dietary fiber; also it is safe and characterized as low-cost ingredients. Moreover, high demands of healthy food in Indonesia encourage the food and beverage manufacture to actively work on it and they have to look for healthy, yet low-cost ingredients so the price of the product will not be too high and fruit pomace is the potential ingredient.

\section{ACKNOWLEDGMENTS}

The authors would like to sincerely thank PT. Sewu Segar Primatama (Re-juve) for the support in the study.

\section{REFERENCES}

[1] N. A. Sagar, S. Pareek, S. Sharma, E. M. Yahia, and M. G. Lobo, Fruit and Vegetable Waste: Bioactive Compounds, Their Extraction, and Possible Utilization," Compr. Rev. Food Sci. Food Saf., vol. 17, no. 3, 2018, pp. 512-531.

[2] M. Shahbandeh, Global production of fresh fruit from 1990 to 2019, Statista, 2021. [Online]. Available:

https://www.statista.com/statistics/262266/globa 1-production-of-fresh-fruit/.

[3] G. Rajauria and B. K. Tiwari, Fruit Juices: An Overview. Elsevier Inc., 2018.

[4] A. Priyadarshini and A. Priyadarshini, Market Dimensions of the Fruit Juice Industry, vol. i. Elsevier Inc., 2018.

[5] Statista, Juices - worldwide, 2021. [Online]. Available: https://www.statista.com/outlook/cmo/non-

alcoholic-

drinks/juices/worldwide?currency=USD .

[6] Statista, Juices - Indonesia, 2021. [Online]. Available:

https://www.statista.com/outlook/cmo/nonalcoholic-

drinks/juices/indonesia?currency=USD .

[7] Euromonitor International, Juice in Indonesia, 2019. [Online]. Available: https://www.euromonitor.com/juice-inindonesia/report .

[8] Rejuve, Rejuve. [Online]. Available: https://www.rejuve.co.id/products.

[9] A. Poli, G. Anzelmo, G. Fiorentino, B. Nicolaus, G. Tommonaro, and P. Di, Polysaccharides from Wastes of Vegetable Industrial Processing: New Opportunities for Their Eco-Friendly Re-Use, Biotechnol. Biopolym., no. June, 2011.

[10] S. G. Rudra, J. Nishad, N. Jakhar, and C. Kaur, Food Industry Waste: Mine of Nutraceuticals, Int. J. Sci. Environment Technol., vol. 4, no. 1,2015, pp. 205-229.

[11] M. Kruczek, B. Drygaś, and C. Habryka, Pomace in fruit industry and their contemporary potential application, World Sci. News, vol. 48, no. June, 2016, pp. 259-265.

[12] S. Microorganisms, G. Media, and P. P. Control, United States Patent ( 19 ), vol. 410, no. 19, 1999, pp. 407-410.

[13] N. Pap, E. Pongrácz, L. Myllykoski, and R. Keiski, Waste minimization and utilization in the food industry: Processing of arctic berries, and extraction of valuable compounds from juiceprocessing by-products, Proc. waste minimization Resour. use Optim. Conf., 2004, pp. 159-168.

[14] K. H. G. K. Kodagoda and R. A. U. J. Marapana, Utilization of fruit processing by-products for industrial applications: A review, Int. J. Food Sci. Nutr., vol. 2, no. 6, 2017, pp. 24-30.

[15] C. Torres-León et al., Food Waste and Byproducts: An Opportunity to Minimize Malnutrition and Hunger in Developing Countries, Front. Sustain. Food Syst., vol. 2, no. September, 2018, pp. 1-17.

[16] L. E. Garcia-Amezquita, V. Tejada-Ortigoza, S. O. Serna-Saldivar, and J. Welti-Chanes, Dietary fiber concentrates from fruit and vegetable byproducts: Processing, modification, and 
application as functional ingredients, Food Bioprocess Technol., vol. 11, no. 8, 2018, pp. 1439-1463.

[17] IGD, PepsiCo: Tropicana Whole Fruit increasing fibre in fruit juice, 2019. [Online]. Available: https://www.igd.com/articles/articleviewer/t/pepsico-tropicana-whole-fruitincreasing-fibre-in-fruit-juice/i/22055.

[18] S. Struck and H. Rohm, Fruit processing byproducts as food ingredients, in Valorization of Fruit Processing By-products, Elsevier, 2020, pp. $1-16$.

[19] J. Jung, Value-added Utilization of Fruit and Vegetable Pomace in Food Packaging, in Food Packaging, CRC Press, 2019, pp. 87-107.

[20] R. H. Liu, Health benefits of fruit and vegetables are from additive and synergistic combinations of phytochemicals, Am. J. Clin. Nutr., vol. 78, no. 3 SUPPL., 2003, pp. 3-6.

[21] Norah O'Shea, Characterisation and application of fruit by-products as novel ingredients in gluten-free products, National University of Ireland, University College, Cork, 2014.

[22] R. C. Skinner, J. C. Gigliotti, K. M. Ku, and J. C. Tou, A comprehensive analysis of the composition, health benefits, and safety of apple pomace, Nutr. Rev., vol. 76, no. 12, 2018, pp. 893-909.

[23] A. M. S. Hussein, M. M. Kamil, N. A. Hegazy, K. F. Mahmoud, and M. A. Ibrahim, Utilization of Some Fruits and Vegetables By-Products to Produce High Dietary Fiber Jam, Food Sci. Qual. Manag., vol. 37, no. 2007, 2015, pp. 3945 .

[24] F. Figuerola, M. L. Hurtado, A. M. Estévez, I. Chiffelle, and F. Asenjo, Fibre concentrates from apple pomace and citrus peel as potential fibre sources for food enrichment, Food Chemistry, vol. 91, no. 3. 2005, pp. 395-401.

[25] N. Grigelmo-Miguel and O. Martín-Belloso, Comparison of Dietary Fibre from By-products of Processing Fruits and Greens and from Cereals, LWT - Food Science and Technology, vol. 32, no. 8. 1999, pp. 503-508.

[26] D. Ocen and X. Xu, "Effect of Citrus Orange (Citrus sinensis) By-product Dietary Fiber Preparations on the Quality Characteristics of Frozen Dough Bread," Am. J. Food Technol., vol. 8, no. 1, 2012, pp. 43-53.

[27] S. M. Naikare, Utilization and Management of
Food Waste, 2019, pp. 165-190.

[28] M. A. Adams and D. M. Keefe, Agency Response Letter GRAS notice no. 000719, Orange Pomace, 2017.

[29] K. A. Mhd Abd Kader et al., Evaluation on physico-chemical properties of pink guava puree residue as bioresource, Int. Food Res. J., vol. 23, no. December, 2016, pp. S125-S131.

[30] L. K. Devi, S. Karoulia, and N. Chaudhary, Preparation of High Dietary Fibre Cookies from Pineapple (Ananas comosus) Pomace, Int. J. Sci. Res., vol. 5, no. 5, 2016, pp. 1368-1372.

[31] H. Kumar, S. K. Katiyar, R. Rakha, A. Soni, and K. Singh, Studies on Pineapple Pomace and Its Qualities, Res. J. Adv. Eng. Sci., vol. 4, no. 1, 2018, pp. 26-27.

[32] M. M. Selani, S. G. C. Brazaca, C. T. Dos Santos Dias, W. S. Ratnayake, R. A. Flores, and A. Bianchini, Characterisation and potential application of pineapple pomace in an extruded product for fibre enhancement, Food Chem., vol. 163, 2014, pp. 23-30.

[33] R. Hemalatha and S. Anbuselvi, Physicohemical constituents of pineapple pulp and waste, J. Chem. Pharm. Res., vol. 5, no. 2, 2013, pp. 240 242.

[34] G. Gurumeenakshi, N. Varadharaju, and R. Rajeswari, Quality Analysis of Mango Fruit Waste for Utilization in Food Products, Int. J. Curr. Microbiol. Appl. Sci., vol. 8, no. 03, 2019, pp. 20-27.

[35] M. L. Sudha, K. Indumathi, M. S. Sumanth, S. Rajarathnam, and M. N. Shashirekha, Mango pulp fibre waste: characterization and utilization as a bakery product ingredient, J. Food Meas. Charact., vol. 9, no. 3, 2015, pp. 382-388.

[36] S. Rana, S. Gupta, A. Rana, and S. Bhushan, Functional properties, phenolic constituents and antioxidant potential of industrial apple pomace for utilization as active food ingredient, Food Sci. Hum. Wellness, vol. 4, no. 4, 2015, pp. 180 187.

[37] Y. Sun, L. Qiao, Y. Shen, P. Jiang, J. Chen, and $\mathrm{X}$. Ye, Phytochemical Profile and Antioxidant Activity of Physiological Drop of Citrus Fruits, J. Food Sci., vol. 78, no. 1, 2013, pp. 37-42.

[38] S. Multari, S. Carlin, V. Sicari, and S. Martens, Differences in the composition of phenolic compounds, carotenoids, and volatiles between juice and pomace of four citrus fruits from 
Southern Italy, Eur. Food Res. Technol., vol. 246, no. 10, 2020, pp. 1991-2005.

[39] L. Sukeksi and M. Sarah, "Characterizations and extraction of polyphenols from residual pulp of pink guava as source of antioxidants," ARPN J. Eng. Appl. Sci., vol. 11, no. 8, 2016, pp. 52095216.

[40] C. W. Wilson, P. E. Shaw, and C. W. Campbell, Determination of organic acids and sugars in guava (Psidium guajava L.) cultivars by highperformance liquid chromatography, J. Sci. Food Agric., vol. 33, no. 8,1982, pp. 777-780.

[41] C. Denny et al., Guava pomace: A new source of anti-inflammatory and analgesic bioactives, BMC Complement. Altern. Med., vol. 13, no. 1, 2013, p. 1.

[42] D. I. S. da Silva, G. D. R. Nogueira, A. G. Duzzioni, and M. A. S. Barrozo, Changes of antioxidant constituents in pineapple (Ananas comosus) residue during drying process, Ind. Crops Prod., vol. 50, 2013, pp. 557-562.

[43] Dole Food Company Inc., Encyclopedia of foods: a guide to healthy nutrition, Choice Rev. Online, vol. 40, no. 01, 2002, pp. 40-0025-400025 .

[44] F. Vendruscolo, P. M. Albuquerque, F. Streit, E. Esposito, and J. L. Ninow, Apple pomace: A versatile substrate for biotechnological applications, Crit. Rev. Biotechnol., vol. 28, no. 1, 2008, pp. 1-12.

[45] S. Djilas, J. Canadanovic-Brunet, and G. Cetkovic, By-products of fruits processing as a source of phytochemicals, Chem. Ind. Chem. Eng. Q., vol. 15, no. 4, 2009, pp. 191-202.

[46] A. Agourram et al., Phenolic content, antioxidant potential, and antimicrobial activities of fruit and vegetable by-product extracts, Int. J. Food Prop., vol. 16, no. 5, 2013, pp. 1092-1104.

[47] A. Nawirska and M. Kwaśniewska, Dietary fibre fractions from fruit and vegetable processing waste,Food Chem., vol. 91, no. 2, 2005, pp. 221225 .

[48] P. Sahni and D. M. Shere, Utilization of fruit and vegetable pomace as functional ingredient in bakery products: A review, Asian J. Dairy Food Res, vol. 37, no. 3, 2018, pp. 202-211.

[49] A. B. Singh, N. Singh, R. Maurya, and A. Kumar, Anti-hyperglycaemic, lipid lowering and antioxidant properties of [ 6 ] -gingerol in $\mathrm{db} / \mathrm{db}$ mice, Int. J. Med. Med. Sci., vol. 1, no. 12, 2009, pp. 536-544.

[50] S. Ötles and S. Ozgoz, Health effects of dietary fiber, Acta Sci. Pol. Technol. Aliment., vol. 13, no. 2, p2014, p. 191-202.

[51] A. Sharoba, M. Farrag, and A. Abd El-Salam, Utilization of Some Fruits and Vegetables Wastes As a Source of Dietary Fibers in Cake Making, J. Food Dairy Sci., vol. 4, no. 9, 2013, pp. 433-453.

[52] A. Nawirska and C. Uklanska, Waste products from fruit and vegetable processing as potential sources for food enrichment in dietary fibre. Acta Sci. Pol. Technol. Aliment., vol. 7, no. 2, 2008, pp. 35-42.

[53] J. W. Anderson et al., Health benefits of dietary fiber, Nutr. Rev., vol. 67, no. 4, 2009, pp. 188 205.

[54] Kementerian Kesehatan Republik Indonesia, Peraturan Menteri Kesehatan Republik Indonesia No. 28 Tahun 2019 Tentang Angka Kecukupan Gizi yang Dianjurkan untuk Masyarakat Indonesia.2019.

[55] V. Oreopoulou and C. Tzia, Utilization of Plant By-Products for the Recovery of Proteins ,2008, pp. 209-232.

[56] K. Younis and S. Ahmad, Waste utilization of apple pomace as a source of functional ingredient in buffalo meat sausage, Cogent Food Agric., vol. 1, no. 1, 2015, p. 1119397.

[57] K. Kołodziejczyk, J. Markowski, M. Kosmala, B. Król, and W. Płocharski, Apple pomace as a potential source of nutraceutical products, Polish J. Food Nutr. Sci., vol. 57, no. 4(B), 2007, pp. 291-295.

[58] M. R. Romero-Lopez, P. Osorio-Diaz, L. A. Bello-Perez, J. Tovar, and A. BernardinoNicanor, Fiber concentrate from orange (Citrus sinensis L.) bagase: Characterization and application as bakery product ingredient, Int. J. Mol. Sci., vol. 12, no. 4, 2011, pp. 2174-2186.

[59] A.-H. Ramadan, "Utilization of Orange Pomace in Processing Low Calories Cake," J. Food Dairy Sci., vol. 3, no. 2, 2012, pp. 63-74.

[60] S. H. Al-Sheraji, A. Ismail, M. Y. Manap, S. Mustafa, R. M. Yusof, and F. A. Hassan, Functional properties and characterization of dietary fiber from mangifera pajang kort. Fruit pulp, J. Agric. Food Chem., vol. 59, no. 8, 2011, pp. 3980-3985. 